/Running title: Economic crisis and municipal employees' job satisfaction/

\title{
MUNICIPAL EMPLOYEES \\ IN THE ERA OF ECONOMIC CRISIS: EXPLORING THEIR JOB SATISFACTION
}

\section{Theodora Papavasili}

$\mathrm{PhD}$ Candidate at University of Patras, Department of Business

Administration of Food and Agricultural Enterprises.

Address: G. Seferi 2, Agrinio 30100, Greece.

E-mail: d.papavasili@yahoo.gr

\section{Achilleas Kontogeorgos}

Dr., Assistant Professor at University of Patras, Department of Business

Administration of Food and Agricultural Enterprises.

Address: G. Seferi 2, Agrinio 30100, Greece.

E-mail: akontoge@upatras.gr

\section{Thomas Siskou}

Dr., Assistant Professor at Western Macedonia University

of Applied Science, Department of International Trade.

Address: Fourka area, Kastoria 52100, Greece.

E-mail: t.siskou@kastoria.teiwm.gr

Fotios Chatzitheodoridis (Corresponding Author)

Dr., Professor at Western Macedonia University of Applied Science,

Department of Agricultural Technology/Division of Agricultural Economics.

Address: Terma Kontopoulou, Florina 53100, Greece.

E-mail: fxtheo@florina.teiwm.gr

\begin{abstract}
The present study examines the level of job satisfaction among municipal employees in Greece, the relation between overall satisfaction and satisfaction that is related with job objective, working conditions, salary, kind of service, collaboration and development prospects, as well as possible repercussions of the economic crisis on it. The data comes from a survey carried out in 2017 on a sample of 196 employees. The survey questionnaire is based on the scales for measuring satisfaction from Spector's "Job Satisfaction Survey".

A basic conclusion of the survey is that the overall satisfaction of employees is mediocre, this picture, though, not having been affected substantially by the implications of the economic crisis. However, it has been found that the study determined those specific satisfaction aspects, namely the department where employees serve and the administrative skills of the heads of the departments, that seem to have positive influence on the generally satisfied employees. The examination of certain aspects of partial job satisfaction aims at improving public management, mainly on the basis of intrinsic rewards, in times of economic instability.
\end{abstract}


Keywords: job satisfaction; public sector; municipal employees; economic crisis; Greece; logistic regression analysis.

Citation: Papavasili, T., Kontogeorgos, A., Siskou, T. \& Chatzitheodoridis, F. (2019). Municipal Employees in the Era of Economic Crisis: Exploring Their Job Satisfaction. Public Administration Issue, Special Issue I (electronic edition), pp. 120-139 (in English); DOI: 10.17323/1999-5431-2019-0-5-120-139.

\section{Introduction}

High performance and efficiency of employees, both in the private and in the public sector, are a primary objective of every administration. In most cases, the efficiency of employees is directly related to their level of satisfaction in the context of their job (Markovits et al., 2007; Huczynski \& Buchanan, 2013), whereas this level of satisfaction is determined by a whole range of factors, work-related or not. Since a government's aim is the optimization of the organizational and administrative structure so that the objectives of public institutions can be achieved (Michalopoulos, 2003), public management, in particular, ought to take into account the level of satisfaction of the employees (Ritz, 2009).

According to Bourantas and Papalexandris (1999), public servants in Greece display a relatively low degree of job satisfaction, which results in poor performances and, subsequently, in the low efficiency of the Greek public services. At the same time, there is a complete lack of competition among public servants, which could otherwise possibly motivate them. This negative image remains invariable as recent researches confirm a similar relationship between the lack of job satisfaction among public servants and their low level of productivity (Fassoulis \& Alexopoulos, 2015).

Throughout the last decade, Greece has been facing a deep fiscal crisis (Chatzitheodoridis et al. 2014) which has exacerbated the already serious problems of the public sector as the income of public servants has shrunk and their labor conditions have deteriorated. The need for a substantial reduction in the budgetary outlay and in the deficit has led to a dramatic decrease in the expenditures on wages over this period as both average wages and the number of public servants has reduced significantly (Ladi, 2014; MIAR, 2016). The decrease in the number of public servants is also due to the retirement of a large proportion of them and to the cessation of hiring new ones in the context of the programs of fiscal adjustment (Eurofound, 2016).

The present paper aims at exploring the level of general satisfaction among local government employees in Greece in the period of the economic crisis, as well as the particular aspects that affect the overall job satisfaction. The structure of the paper is the following: it starts with a review of the relevant bibliography; subsequently, the methodology of the research is introduced; a section with the outcomes and discussion follows; and the paper ends with the conclusions derived from the research about the level of job satisfaction of local government employees. 


\section{Literature review}

\section{Job satisfaction and public servants}

According to Spector (1997), job satisfaction is a scale to measure how much people love their job and its various aspects. Cranny et al. (1992) define job satisfaction as the feeling that results from the comparison between the actual, the desired and the expected outcomes of a job. In order to achieve job satisfaction, motivation is a key principle, which is inextricably linked to the existence of a need. Needs, either basic or related with the value system, lead in turn to the respective objectives, while, according to Robbins and Judge (2013), motivation is necessary for the objectives to be achieved. Job satisfaction is the link between theories of motivation and their implementation in workplaces and thus constitutes a crucial factor for the success of any organization (Jex \& Britt, 2008). Satisfied employees usually work more and present higher rates of productivity, which demonstrates that satisfaction relates to the level of effectiveness of an organization, either private or public (Ostroff, 1992; Gould-Williams, 2003; Bakotić, 2016).

The relatively better employee remuneration and working conditions in the public sector give it an advantage over the private sector internationally (Germany, United Kingdom, Italy, Greece) in terms of job satisfaction, as many empirical studies suggest (Danzer, 2013). The difference between the two sectors, in job security as well as earnings, help maintain this relative gap in the level of job satisfaction, and the specific reasons for this gap grow even more significant in times of financial crises and economic instability (Luechinger et al., 2010). The investigation of the incentives leading to job satisfaction, in particular, is a subject largely discussed in the relevant literature (Perry \& Wise, 1990; Georgellis \& Tabvuma, 2010; Wright \& Davis, 2003). Employee job satisfaction in the public sector is related to the possibility for them to achieve the goals and outcomes set by the organization or the service they serve, as well as with opportunities that their work offers for professional advancement (Boyne, 2003; Prysmakova et al., 2017).

In Greece, finding work in the public sector has been a major target for Greek citizens over the last forty years due to public jobs offering more security than private sector jobs (Manolopoulos, 2006; Maroudas, 2009). This pursuit increased the dependence between the politicians and their voters and increased corruption, also (Sotiropoulos, 2007; Ladi, 2014). Voters were willing to vote the politicians who would help them find work in the public sector, and at the same time politicians help them to take jobs without merit criteria, to get their vote.

According to the conclusions of Manolopoulos (2006), it seems that the public sector in Greece used to offer public servants more extrinsic than intrinsic rewards. Extrinsic rewards (such as decent wages and increased job security) were also used to motivate employees to improve their productivity. The same research has recorded the needs of the employees and the factors of their satisfaction, which, however, vary according to their demographic features and their skills. Papanis and Giavrimis (2007) have highlighted the importance of the distinction of roles and tasks for the satisfaction that employees derive from their jobs. The more confusion there is over tasks and duties, the greater the discontent and dissatisfaction of the employees will be. In their analysis of data gathered for the years 1995 
to 2001 regarding employees in the public and in the private sector, Demoussis and Giannakopoulos (2007) found that the level of satisfaction of employees in the public sector exceeded the respective level of employees in the private sector, with regular working hours emerging as the most important factor, which employees would be willing to preserve even by sacrificing a part of their salary. Through the analysis that they carried out among permanent civil servants and contract staff in the Greek public sector, Batiou and Valkanos (2008) detected a modest level of job satisfaction. This level of satisfaction related, to a limited extent, to the existence of extrinsic rewards, whereas the only motivation that was associated with a high degree of intrinsic satisfaction was the type of work.

However, most surveys on the level of satisfaction of civil servants in Greece have been carried out in the field of public health. Markovits et al. (2007) demonstrated that employees in the health sector that are motivated by incentives, as well as those who present high levels of organizational commitment, are more satisfied in comparison with those motivated by factors such as the working conditions, the cooperation or the hierarchy, and the object of department. In their examination of the leadership of the hospitals of the national health system, Pantouvakis and Mpogiatzidis (2007) concluded that there is a positive correlation between organizational learning, particularly improvement through continuous learning, and the level of satisfaction at work. Alexias et al. (2010) found out that job satisfaction among medical staff is low, which is mainly related to the level of salaries and opportunities for promotion. During the years of the economic crisis in Greece, Pelechas and Antoniadis (2012) also pointed out that the medical and nursing staff in hospitals faces serious problems in their working environment, mainly due to the rigid administration system, which does not inspire confidence and does not promote job satisfaction. The high level of dissatisfaction that the researchers detected is related to the size of the hospitals serving major urban agglomerations and to the increased workload combined with understaffing. Ioannou et al. (2010) reached similar conclusions in their survey regarding nursing staff, according to which the adverse working conditions were found to affect both the level of job satisfaction and their quality of life, as well as their health. At this point, it should be mentioned that Spyropoulos et al. (2005), in an older study, discovered that Greek civil servants have health problems, particularly low back pain, which were associated with factors such as age, gender, body mass index, posture and distance from the computer monitor. This health problem was related positive also according Spyropoulos et al. with the not satisfied civil servants by their jobs.

It is interesting, lastly, to consider the findings of the research of Karkatsoulis et al. (2005), who examined the attitudes, incentives and beliefs of public servants, as well as of volunteers for the organization of the Olympic Games of 2004 in Greece and found that national identity was the only motivation regarding their work and their satisfaction with it.

\section{Economic crisis in Greece and the public sector}

The deficiencies and problems of the economies of the European South have created fertile ground for the transmission of the global economic crisis, which broke out in 2008 in Europe. Greece, with its combination of high public debt, 
fiscal deficits and weak productive base, found itself in need of financial support from the Euro-zone, which in turn created an economic mechanism consisting of the European Commission, the European Central Bank and the International Monetary Fund, in order to deal with the situation (Ladi, 2011). From 2010 to 2018 Greece signed three Memorandum of Economic and Financial Policies and continues to implement the third of these in order to achieve fiscal adjustment and resolution. From the very beginning, the need emerged for immediate measures to reduce the fiscal deficits, which had been aggravated in the context of the reorganization measures of the Memorandum. The public sector was driven to "compulsory" reformation, which did not aim at improving its low level of efficiency and productivity, neither at upgrading its quality, but exclusively at reducing its high operational cost and, consequently, public expenditure.

More specifically, according to the Ministry of the Interior and Administrative Reconstruction (MIPR, 2016), between 2009 and 2015 the number of permanent public servants was reduced by $18 \%$ (Figure 1) and the Gross Domestic Product (GDP) of the country decreased by $26 \%$. During the same period, total salary costs in the Greek public sector were reduced by $31 \%$, namely from 31,013 billion euros in 2009 to 21,477 in 2105, whereas as a percentage of the GDP they fell from $13.1 \%$ in 2009 to $12.2 \%$ in 2015 , this gap being so narrow only due to the significant decline of the GDP (ELIAMEP, 2015). The average wage has been reduced by $14.6 \%$ in the public sector, as opposed to a decrease of $17.9 \%$ in the private sector, while the reduction in the number of employees in the private sector, which exceeded 20\% (ELSTAT, 2015), was also significant, making unemployment in the country skyrocket, from $7.8 \%$ in 2008 to $27.5 \%$ in 2013 (ELSTAT, 2017).

\section{Figure 1: Number of Greek permanent civil servants between the years 2009 and 2015}

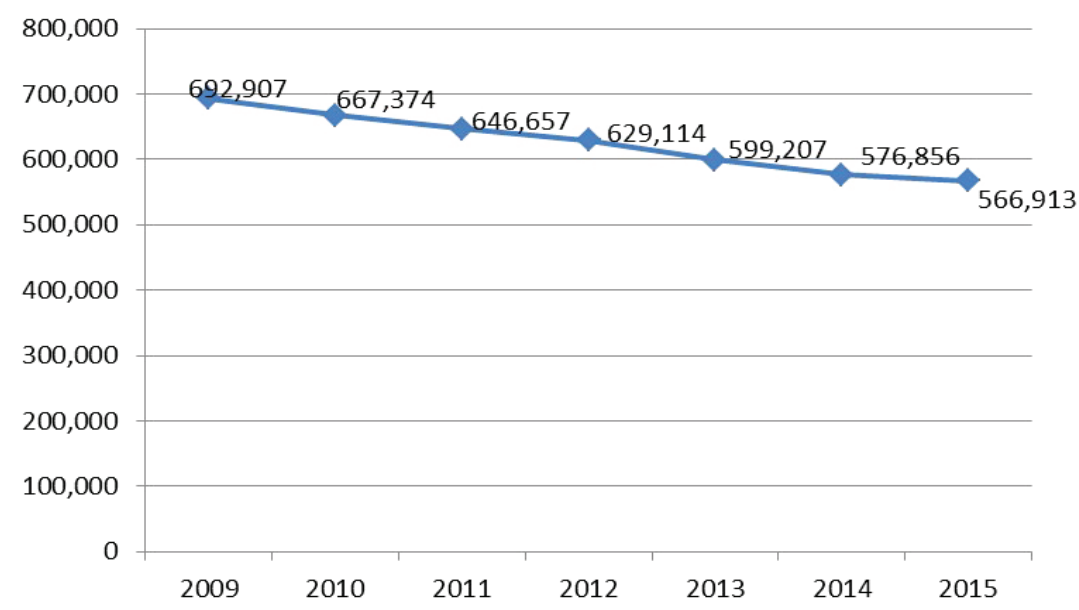

Data source: Ministry of Interior and Administrative Reconstruction, 2016.

In Greece, the category of public servants comprises both permanent employees and private open-ended contract staff (i.e. legal persons governed by either public or private law) serving in the central government as well as in local authorities (em- 
ployees in the municipalities and in regional administrative units). Of the 565,671 public servants in the country, 82,859 (14.6\%) serve in local authorities (MIAR, 2017).

\section{Survey methodology}

The survey was conducted in seven (7) representative municipalities out of the nineteen (19) municipalities in the region of Western Greece (Figure 2) and it concerns permanent municipal servants of the categories of university, technological university and secondary education. The collection of data was carried out in the first semester of 2017 using a questionnaire. A trial version was first distributed to a limited number of employees in order to detect possible confusing or unclear questions, and the final version of the questionnaire was distributed to 200 randomly selected municipal employees in the municipalities in the region of Western Greece who met the requirements (that is existing permanent public servants having secondary or higher education). Out of the 200 completed questionnaires, 196 were considered credible and constituted the final sample. The allocation of the sample by municipality as well as the population and area of each municipality are shown in the matrix of the Figure 2.

\section{Figure 2: Map of Greece indicating the Western Greece Region and a matrix with the names of municipalities, their size (area and population) and the survey sample}

\begin{tabular}{|l|r|r|r|r|}
\hline & \\
& \\
& \\
\hline
\end{tabular}

According to the findings of the survey, the sample displays the demographic characteristics and employment features shown in Table 1. More specifically, the majority of the respondents were women (52.6\%), married (47.6\%), between 40 and 49 years old (60.8\%) and had a university education (42.9\%). Regarding their employment status, the majority worked for the municipality of Agrinion (54.6\%), mostly as administrative staff $(50.0 \%)$, with 16 to 20 years of previous service (30.6\%) and not occupying any position of responsibility (77.6\%).

The questionnaire is divided into two parts and contains 56 questions in total. The first part consists of two sections containing questions about the demographic data and information about the service of the respondents respectively. The second part constitutes the core of the questionnaire and includes ten sections based on the Job Satisfaction Survey - JSS of Paul E. Spector (1985), but specially adjusted to the 
needs of the present survey. Eight out of the ten sections of this core regard the basic aspects of job satisfaction, that is the perceptions of the respondents about: 1) the municipality they work for, 2) the department they work in, 3) their subject of work, 4) their cooperation and communication with colleagues and citizens, 5) their working conditions, 6) their superiors and the administration, 7) the perspectives for training and professional development, and 8) the remuneration for their work. For this section a Likert scale ranging from 1 to 6 was used. The two last sections of the second part include questions regarding, first, the overall satisfaction of the employees and, second, the effect of the economic crisis on their income, their working conditions and their level of job satisfaction.

Table 1

\section{Demographic characteristics and employment features of the participants in the survey}

\begin{tabular}{|c|c|c|}
\hline Characteristics & Count & Percentage, $\%$ \\
\hline \multicolumn{3}{|l|}{ Gender } \\
\hline Male & 93 & 47.4 \\
\hline Female & 103 & 52.6 \\
\hline \multicolumn{3}{|l|}{ Marital status } \\
\hline Married & 156 & 47.9 \\
\hline Unmarried & 25 & 46.6 \\
\hline Divorced /Widowed /Other & 15 & 5.4 \\
\hline \multicolumn{3}{|l|}{ Age } \\
\hline $20-29$ & 1 & 0.5 \\
\hline $30-39$ & 10 & 5.1 \\
\hline $40-49$ & 118 & 60.2 \\
\hline $50-59$ & 55 & 28.1 \\
\hline$>60$ & 12 & 6.1 \\
\hline \multicolumn{3}{|l|}{ Education (in years) } \\
\hline Less than 12 years (High school) & 64 & 32.7 \\
\hline More than 12 years (Technological University) & 24 & 12.2 \\
\hline More than 12 years (University) & 84 & 42.9 \\
\hline More than 16 years (Postgraduate studies) & 24 & 12.2 \\
\hline \multicolumn{3}{|l|}{ Specialty } \\
\hline Administrator & 98 & 50.0 \\
\hline Engineer & 24 & 12.2 \\
\hline Geotechnical & 16 & 8.2 \\
\hline Economist & 23 & 11.7 \\
\hline Information technology & 7 & 3.6 \\
\hline Other & 28 & 14.3 \\
\hline
\end{tabular}




\begin{tabular}{|l|c|c|}
\hline \multicolumn{1}{|c|}{ Characteristics } & Count & \\
\hline Years of professional experience & 7 & 6.1 \\
\hline $0-10$ & 50 & 25.5 \\
\hline $11-15$ & 60 & 30.6 \\
\hline $16-20$ & 27 & 13.8 \\
\hline $21-25$ & 47 & 24.0 \\
\hline$>25$ & & \\
\hline Position of responsibility & 152 & 77.6 \\
\hline Employee & 34 & 17.4 \\
\hline Head of Department & 10 & 5.1 \\
\hline Director & & \\
\hline
\end{tabular}

Source: Results Analysis

The collected data were analyzed statistically according to the steps and techniques that are presented in Figure 3 (methodological framework).

\section{Figure 3: Methodological Framework}

Data Collection

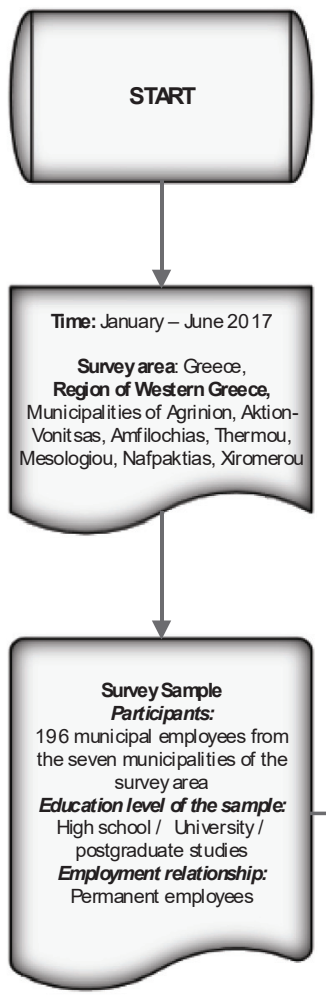

Survey Methodology

Data Analysis

Results

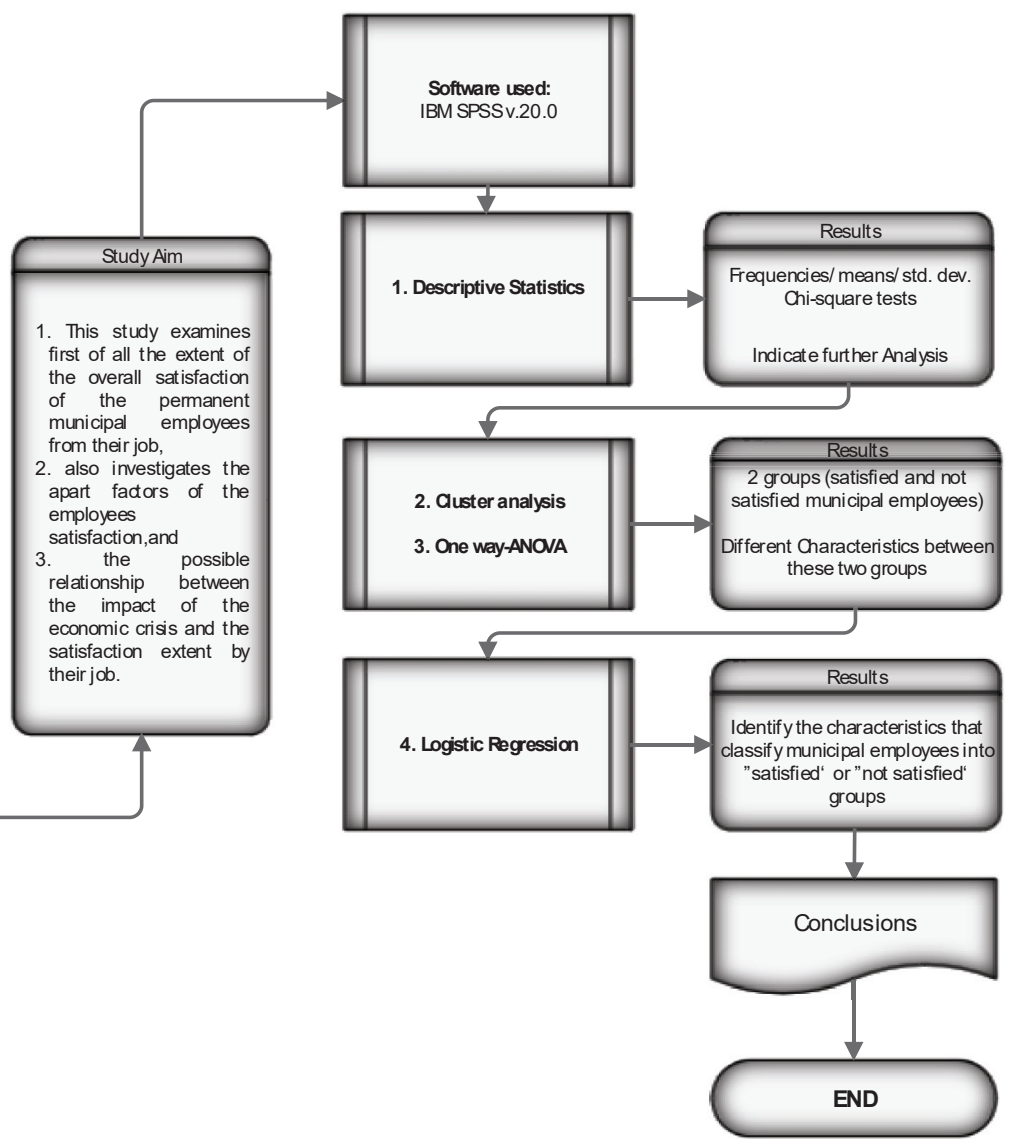


The basic results were given by descriptive analysis. Two cross tabs were used to test the differences: 1) between the range of overall job satisfaction of the participants and their work prospects, and 2) between the two clusters (satisfied and not satisfied) and their municipalities of employment. Further analysis was carried out with the method of clusters analysis, which indicated two groups (satisfied municipal employees and not satisfied). One-way ANOVA was performed to test the differences and characteristics of the two groups. The final technique used was logistic regression analysis. This analysis is useful in cases where we want to model the event probability for a categorical response variable with two outcomes. Since the probability of an event must lie between 0 and 1, it is impractical to model probabilities with linear regression techniques, because the linear regression model allows the dependent variable to take values greater than 1 or less than 0 . The logistic regression model is a type of generalized linear model that extends the linear regression model by linking the range of real numbers to the range $0-1$ (Field, 2005). In this study, the municipal employees were examined on the basis of a set of personal views and factors that relate to their overall job satisfaction as well as to aspects of partial satisfaction, such as their working object and prospects, the department where they work and the administrative capacity of the head of the department (Table 2). For all statistical analyses, Statistical Package for Social Sciences (SPSS) version 20.0 was used.

Table 2

\section{Mean value and standard deviation of the partial satisfaction aspects and the overall job satisfaction of the survey respondents}

\begin{tabular}{|l|c|c|c|c|c|}
\hline Partial aspects of Job satisfaction in relation with: & Count & Mean & Std Dev. & Min value & Max value \\
\hline Municipality of employment & 196 & 4.109 & 0.755 & 1 & 5 \\
\hline Department of work & 196 & 4.568 & 0.982 & 1 & 5 \\
\hline Working object & 196 & 3.789 & 0.520 & 1 & 5 \\
\hline Cooperation/communication & 196 & 3.817 & 0.559 & 1 & 5 \\
\hline Working conditions & 196 & 4.448 & 1.003 & 1 & 5 \\
\hline Head of department/leadership & 196 & 4.443 & 0.861 & 1 & 5 \\
\hline Work prospects & 196 & 3.607 & 1.077 & 1 & 5 \\
\hline Salary & 196 & 3.531 & 0.703 & 1 & 5 \\
\hline Overall satisfaction & $\mathbf{1 9 6}$ & $\mathbf{2 . 9 3 8}$ & $\mathbf{0 . 5 5 8}$ & $\mathbf{1}$ & $\mathbf{5}$ \\
\hline
\end{tabular}

Source: Results Analysis

\section{Results}

Municipal employees present a mediocre degree of overall job satisfaction, ( mean $=2.938$, standard deviation $=0.558$, ranged from 1 to 5 ), as shown in Table 2. However, when considering aspects of partial satisfaction, the respondents were found to be seemingly more satisfied, particularly with the department they 
worked in (4.58), their working conditions (4.44) as well as the administration of the head of their department (4.44). A lower grade was given to the satisfaction aspect relating to their earnings (3.53). The mean values of the aspects of partial satisfaction are presented in Figure 4 and whereas the divergence between the level of overall satisfaction and its partial aspects is notable in that municipal employees are only moderately satisfied in general, they are clearly more satisfied with particular aspects, the sum of which should probably add up to, or at least approach, the level of their overall satisfaction.

\section{Figure 4: Mean value of the job satisfaction partial aspects of the survey respondents}

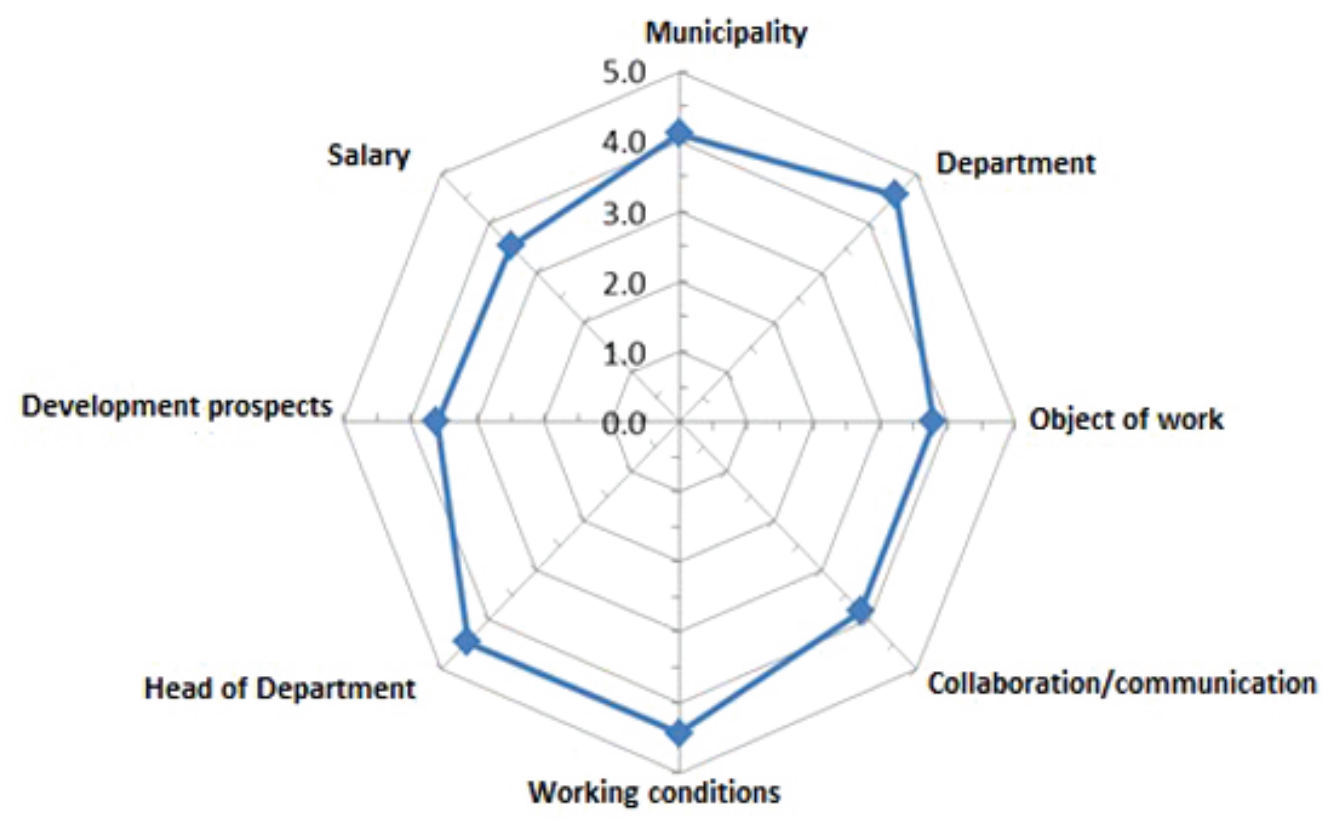

All the respondents (100\%) gave a positive answer to the question about whether they have suffered income losses and a worsening of their working conditions due to the economic crisis or not. More specifically, in the 8-year period between 2010 and 2017, all 196 respondents had lost $40 \%$ to 50\% of the income they used to earn before 2010. According to their answers, out of this overall reduction, $25-30 \%$ is due to the decrease in their salary and the elimination of almost all allowances and bonuses and $15-20 \%$ is due to the significant increase in direct and indirect taxation, as well as in insurance contributions. Universal agreement is also recorded in the answers about the deterioration of working conditions because of the economic crisis, which the employees attribute to the increase in workload due to the reduction in the number of employees as well as to the cuts in the operating expenses of the municipalities. Despite those answers, though, nearly all municipal employees (95\%) do not directly associate the level of their overall job satisfaction with the repercussions of the economic crisis, knowing that those repercussions are common for all workers and pensioners and 
that an important portion of the economically active population ended up being unemployed because of the crisis.

The economic crisis has caused massive pessimism among Greek society, and therefore it has been deemed necessary to examine the level of job satisfaction of municipal employees in relation to their view about their professional future. There were three possible answers about the professional future: a future worse (that is, with more disadvantages) than the current situation, a neutral development, or a better future (with more advantages). The chi-squared test $(\mathrm{a}<0.05)$ has shown that there are differences, as employees less satisfied with their job seem to be looking to the future with more pessimism, whereas those who are more optimistic about it are seemingly those who are also more satisfied with their current situation (Table 3).

Table 3

\section{Overall job satisfaction by the work prospects of the survey participants}

\begin{tabular}{|c|c|c|c|c|c|}
\hline \multicolumn{6}{|c|}{ Work prospects } \\
\hline & & $\begin{array}{c}\text { More disad- } \\
\text { vantages than } \\
\text { advantages }\end{array}$ & Neutral & $\begin{array}{l}\text { More advan- } \\
\text { tages than } \\
\text { disadvantages }\end{array}$ & Total \\
\hline \multirow{11}{*}{$\begin{array}{l}\text { Job } \\
\text { Satisfaction }\end{array}$} & Very Dissatisfied & 3 & 0 & 0 & 3 \\
\hline & $\%$ & $100.0 \%$ & $0.0 \%$ & $0.0 \%$ & $100,0 \%$ \\
\hline & Partly Dissatisfied & 12 & 0 & 4 & 16 \\
\hline & $\%$ & $75.0 \%$ & $0.0 \%$ & $25.0 \%$ & $100,0 \%$ \\
\hline & Neutral & 5 & 10 & 22 & 37 \\
\hline & $\%$ & $0.9 \%$ & $82.3 \%$ & $16.8 \%$ & $100,0 \%$ \\
\hline & Partly Satisfied & 1 & 93 & 19 & 113 \\
\hline & $\%$ & $0.0 \%$ & $88.9 \%$ & $11.1 \%$ & $100,0 \%$ \\
\hline & Very Satisfied & 0 & 24 & 3 & 27 \\
\hline & $\%$ & $10.7 \%$ & $64.8 \%$ & $24.5 \%$ & $100,0 \%$ \\
\hline & Total & 21 & 127 & 48 & 196 \\
\hline
\end{tabular}

Chi square test: Pearson Chi-Square 149.512, df= 8, Asymp. Sig. (2-sided) $=0.00$

Cluster analysis was performed in order to further examine the aspects of partial satisfaction, where the respondents were divided into two groups: those who can be considered satisfied (117) and those not satisfied with their job (79). The statistical chi-squared test $(\mathrm{a}<0.05)$ that was performed between those two groups and the municipalities they work for has shown that there are differences, as it seems that most satisfied employees serve in the municipalities of Agrinion and Mesologgiou, which are by far the largest ones, whereas most non-satisfied employees work for smaller municipalities (Table 4). This suggests a tendency of the number of satisfied employees to reduce as the municipality that they work for also reduces. 
Table 4

Satisfied and not satisfied employees by the municipalities of employment

\begin{tabular}{|c|c|c|c|c|}
\hline & & Satisfied & Not Satisfied & Total \\
\hline \multirow{14}{*}{$\begin{array}{l}\text { Municipality } \\
\text { of employment }\end{array}$} & Agrinion & 68 & 39 & 107 \\
\hline & $\%$ & $58.1 \%$ & $49.4 \%$ & $54,6 \%$ \\
\hline & Aktion-Vonitsas & 6 & 7 & 13 \\
\hline & $\%$ & $5.1 \%$ & $8.9 \%$ & $6,6 \%$ \\
\hline & Amfilochias & 8 & 8 & 16 \\
\hline & $\%$ & $6.8 \%$ & $10.1 \%$ & $8,2 \%$ \\
\hline & Thermou & 1 & 6 & 7 \\
\hline & $\%$ & $0.9 \%$ & $7.6 \%$ & $3,6 \%$ \\
\hline & Mesologgiou & 12 & 4 & 16 \\
\hline & $\%$ & $10.3 \%$ & $5.1 \%$ & $8,2 \%$ \\
\hline & Nafpaktias & 17 & 8 & 25 \\
\hline & $\%$ & $14.5 \%$ & $10.1 \%$ & $12,8 \%$ \\
\hline & Xiromerou & 5 & 7 & 12 \\
\hline & $\%$ & $4.3 \%$ & $8.9 \%$ & $6,1 \%$ \\
\hline \multicolumn{2}{|l|}{ Total } & 117 & 79 & 196 \\
\hline
\end{tabular}

Chi square test: Pearson Chi-Square 12.172, $\mathrm{df}=6$, Asymp. Sig. (2-sided) $=0,058$

Table 5 presents the one-way analysis of variance (one-way ANOVA) of the partial aspects affecting the level of job satisfaction for the groups (clusters) of municipal employees that were formed in the previous step of the analysis. The results of the analysis of variance show that only the aspects regarding a) the views of the employees about their subject of work and b) their views about cooperation/communication seem not to have a particularly significant effect on the overall satisfaction of municipal employees ( sig. $=0.857$ and sig. $=0.441>0.05$ respectively). All other aspects have an important effect on the decision to declare to be satisfied with their job.

Table 5

\section{One-way ANOVA analysis for the two clusters of municipal employees}

\begin{tabular}{|l|l|l|l|l|l|l|l|}
\hline $\begin{array}{l}\text { Dimensions } \\
\text { of satisfaction }\end{array}$ & $\begin{array}{c}\text { Cluster } \\
\text { of employees }\end{array}$ & Count & $\begin{array}{c}\text { Mean } \\
\text { value }\end{array}$ & Std. Dev. & $\begin{array}{c}\text { Mean } \\
\text { Square }\end{array}$ & F test & Sig. \\
\hline \multirow{2}{*}{$\begin{array}{l}\text { Municipality } \\
\text { of employment }\end{array}$} & Not satisfied & 79 & 3.89 & 0.829 & 5.996 & 10.998 & $\mathbf{0 . 0 0 1}$ \\
\cline { 2 - 8 } & Satisfied & 117 & 4.25 & 0.669 & 0.545 & & \\
\cline { 2 - 8 } & Total & 196 & 4.10 & 0.757 & & & \\
\hline \multirow{2}{*}{$\begin{array}{l}\text { Department } \\
\text { of work }\end{array}$} & Sot satisfied & 79 & 4.09 & 1.047 & 29.727 & 36.363 & $\mathbf{0 . 0 0 0}$ \\
\hline & Satisfied & 117 & 4.888 & 0.793 & 0.817 & & \\
\cline { 2 - 8 } & Total & 196 & 4.56 & 0.982 & & \\
\hline
\end{tabular}




\begin{tabular}{|c|c|c|c|c|c|c|c|}
\hline $\begin{array}{l}\text { Dimensions } \\
\text { of satisfaction }\end{array}$ & $\begin{array}{c}\text { Cluster } \\
\text { of employees }\end{array}$ & Count & $\begin{array}{l}\text { Mean } \\
\text { value }\end{array}$ & Std. Dev. & $\begin{array}{l}\text { Mean } \\
\text { Square }\end{array}$ & F test & Sig. \\
\hline \multirow{3}{*}{ Working object } & Not satisfied & 79 & 3.79 & 0.604 & 0.009 & .033 & 0.857 \\
\hline & Satisfied & 117 & 3.78 & 0.457 & 0.272 & & \\
\hline & Total & 196 & 3.78 & 0.520 & & & \\
\hline \multirow{3}{*}{$\begin{array}{l}\text { Cooperation/ } \\
\text { communication }\end{array}$} & Not satisfied & 79 & 3.77 & 0.623 & 0.187 & .596 & 0.441 \\
\hline & Satisfied & 117 & 3.84 & 0.513 & 0.314 & & \\
\hline & Total & 196 & 3.81 & 0.559 & & & \\
\hline \multirow{3}{*}{$\begin{array}{l}\text { Working condi- } \\
\text { tions }\end{array}$} & Not satisfied & 79 & 4.04 & 10.006 & 21.971 & 24.427 & 0.000 \\
\hline & Satisfied & 117 & 4.72 & 0.907 & 0.899 & & \\
\hline & Total & 196 & 4.44 & 10.003 & & & \\
\hline \multirow{3}{*}{$\begin{array}{l}\text { Head } \\
\text { of department/ } \\
\text { leadership }\end{array}$} & Not satisfied & 79 & 4.04 & 0.950 & 20.767 & 32.532 & 0.000 \\
\hline & Satisfied & 117 & 4.71 & 0.678 & 0.638 & & \\
\hline & Total & 196 & 4.44 & 0.861 & & & \\
\hline \multirow{3}{*}{ Work prospects } & Not satisfied & 79 & 3.14 & 1.121 & 27.938 & 27.293 & 0.000 \\
\hline & Satisfied & 117 & 3.91 & 0.930 & 1.024 & & \\
\hline & Total & 196 & 3.60 & 1.077 & & & \\
\hline \multirow{3}{*}{ Salary } & Not satisfied & 79 & 3.36 & 0.729 & 3.762 & 7.869 & 0.006 \\
\hline & Satisfied & 117 & 3.64 & 0.664 & 0.478 & & \\
\hline & Total & 196 & 3.53 & 0.703 & & & \\
\hline
\end{tabular}

Source: Results Analysis.

However, the analysis of variance can only be used to indicate the statistically significant differences in the factor under consideration and not to point out how those differences affect the overall satisfaction. Therefore, logistic regression analysis was performed to detect the relationship between the aspects of partial satisfaction (described above; Table 2) and the way those aspects affect the employees so that the latter consider themselves satisfied with their job. Logistic regression analysis is useful in cases where it is necessary to predict the probability of something occurring between two outcomes. In this case, logistic regression was used to predict satisfied and dissatisfied employees, based on the two employees' groups formed by the previous cluster analysis (coded with: 0 for non-satisfied employees and 1 for satisfied employees). The results of the logistic regression analysis are presented in Table 6. The results show that only two partial aspects of satisfaction affect the prediction in a positive relationship ie., leadership/head of the department and their perception about the department they work in. Thus, according to the model, if the value of the aforementioned dependent variables between two respondents are different, the respondent with the increased value for this variable will belong to the satisfied group. Otherwise, if public management succeeds to improve (increased value for the variable) the municipal employees' perceptions about the department where they work and the departments' leadership, then it is possible these employees will declare themselves as satisfied in their work. 
Table 6

\section{Logistic regression analysis for the partial aspects of municipal employees satisfaction that affect the overall job satisfaction}

\begin{tabular}{|c|c|c|c|c|c|}
\hline Variables & B & S.E. & Statistic Wald & Wald Sig & $\operatorname{Exp}(B)$ \\
\hline Dependent variable satisfied or not employees & \multicolumn{5}{|c|}{$\begin{array}{l}117 \text { Satisfied employees (coded one) } \\
79 \text { Not satisfied employees (coded Zero) }\end{array}$} \\
\hline Aspects for the municipality where he serves & \multicolumn{5}{|c|}{ Excluded in the Final Assessment Model ${ }^{* 1}$} \\
\hline Working object & \multicolumn{5}{|c|}{ Excluded in the Final Assessment Model ${ }^{* 1}$} \\
\hline Cooperation/communication & \multicolumn{5}{|c|}{ Excluded in the Final Assessment Model ${ }^{\star 1}$} \\
\hline Working prospects & \multicolumn{5}{|c|}{ Excluded in the Final Assessment Model ${ }^{* 1}$} \\
\hline Salary & \multicolumn{5}{|c|}{ Excluded in the Final Assessment Model ${ }^{* 1}$} \\
\hline Department where he serves & 0.780 & 0.196 & 15.803 & $0.00^{*}$ & 2.182 \\
\hline Leadership/Head of department & 0.812 & 0.225 & 13.041 & $0.00^{\star}$ & 2.253 \\
\hline Fixed term & -6.727 & 1.248 & 29.052 & 0.00 & 0.001 \\
\hline
\end{tabular}

${ }^{* 1}$ The estimation method used (Forward Stepwise, Wald) omits in the final assessment variables that are not significant $\mathrm{R}^{2}=$ 0,485 ( $\mathrm{Chi}^{2}$ 4,837, df = 8 - Hosmer \& Lemeshow), 0.217 (Cox \& Snell), 0,293 (Nagelkerke)

Significance: ${ }^{\star} \mathrm{p}<0.01,{ }^{\star *} \mathrm{p}<0.05,{ }^{* *} \mathrm{p}<0.1$

The different formulas for $\mathrm{R}^{2}$ (Hosmer \& Lemeshow, Cox \& Snell, Nagelkerke) show that the estimated model matches the data sufficiently and could predict correctly approximately three out of every four cases. The classification table (Table 7) shows that the estimated model can predict correctly 51.9\% (41 out of 79 cases) for not satisfied employees and 101 out of 117 cases (86.3\%) for satisfied municipal employees. In total, for both satisfied and not satisfied employees, the model correctly predicts $72.4 \%$ of the examined cases.

Table 7

Binary logistic regression results classification table

\begin{tabular}{|c|c|c|c|}
\hline & \multicolumn{2}{|c|}{ Forecast } & \multirow{2}{*}{ Forecast rate, $\%$} \\
\hline & Not-satisfied employees & Satisfied employees & \\
\hline Not satisfied & 41 & 38 & 51.9 \\
\hline Satisfied & 16 & 101 & 86.3 \\
\hline Total & & & 72.4 \\
\hline
\end{tabular}

Source: Results Analysis

In the final instance, the logistic regression analysis seems to indicate that there are two aspects of partial satisfaction that can determine whether the municipal employees are satisfied with their job or not. These aspects concern their views about a) the department (including the way it is organized) that they serve in, and b) the administration of the head of the department. 
To sum up, municipal employees state that they are fairly satisfied when they are directly asked if they are satisfied with their job. However, when partial aspects of satisfaction are examined then it is clear that there are two groups of employees; satisfied and not satisfied. These two groups differ (statistically) mainly in the way they perceive aspects of the way they perceive their department organization and their department's leadership.

\section{Discussion}

From the demographic data, as shown in the relevant table (Table 1), it is already evident that the economic crisis has induced changes in the profile of the active municipal employees, particularly in their age profile. The departure of a large number of public servants, mainly due to massive retirement as well as to the initially zero and, afterwards, very restricted rate of replacement with new ones (the rate of replacement in the public sector was zero in 2012 and 1 recruitment for every 3.6 retired employees in 2015) (MIAR, 2016; Eurofound, 2016), is also reflected in the 196 municipal employees of the survey sample. Only $11 \mathrm{em}$ ployees (5.6\%) belonged to the age group between 20 and 39 years old, and only one out of the 11 was below 30. This fact is also confirmed on the national level, as, according to the Ministry of Interior and Administrative Reconstruction (MIAR, 2017), the average age of civil servants in Greece has risen from 43.1 in 2011 to 45.3 in 2015.

According to the survey, municipal employees have a mediocre level of overall job satisfaction. This conclusion is also confirmed by similar surveys that have been carried out in Greece (Batiou \& Valkanos, 2008; Alexias et al., 2010; Ioannou et al., 2010). What is interesting is that, according to their answers, most public servants do not directly take the repercussions of the economic crisis into account in their assessment about their overall job satisfaction, although they have all lost nearly half their income and are facing more unfavorable working conditions amid the crisis than before it. As a municipal employee characteristically mentioned: "the crisis is a general evil, and nobody is satisfied with anything anymore. It didn't only affect our job but also our entire lives and those of our children". Perhaps the judgment of the municipal employees is influenced by the difficult working conditions which they can see prevailing in the Greek economy after the outbreak of the economic crisis, such as the high unemployment rate in the country, the serious loss of jobs in the private sector, and the promotion of new "flexible" forms of employment (ELSTAT, 2017) that relate to very low salaries and precarity. They probably understand that private sector workers, the unemployed and those with lower income in the country are faced with more adverse economic conditions than them, as they themselves continue to work with a certain degree of security due to the permanency of their job and keep earning a certain income, even restricted. Such considerations are maybe the reason why they do not take the economic crisis into account when determining their overall job satisfaction as well as the reason for their more optimistic assessments about their professional future, reckoning that in the near future the crisis may be under control and their previous privileges/ advantages at work will emerge again. The latter assumption is related to the result 
of the chi-squared statistical test of Table 3, i.e. with the optimistic view of satisfied municipal employees, who expect a more positive future, with more advantages than their current situation, in contrast with non-satisfied employees.

The remuneration issue is a significant aspect of partial job satisfaction, which seems to satisfy municipal employees (even those belonging to the satisfied group) less than all other satisfaction aspects. It should be noted that the remuneration of employees who work for the local authorities is not determined by those local or regional authorities, but by the central government. Therefore, the relatively low level of satisfaction among employees seems justified given the important cuts in their salary which they have suffered as public servants in the previous period, whereas surveys in other public services in Greece after 2008 also record dissatisfaction with the level of salaries (Batiou \& Valkanos, 2008; Alexias et al., 2010).

Logistic regression shows that, among all aspects of partial satisfaction, only two are so important as to include a municipal employee in the group of the satisfied. Those two aspects are the organization of the municipal department where the employees work and the head of their department in terms of his or her administration. There is a statistically significant correlation between those two aspects of partial satisfaction and the overall level of satisfaction, as well as between the two aspects themselves. Employees who appreciate the skills and the effort that their superiors make to solve the problems and to improve working conditions in their department are probably more satisfied with the administration as well as with the organization of the department, and thus make their own effort to improve the services they provide to the public. When administering the department efficiently, the head, in turn, encourages employees who try to carry out their work, thus improving the organizational situation of the department. From an organizational viewpoint, finally, a department administered by a competent and effective head, as well as by employees that are satisfied and willing to work, achieves further qualitative improvement of the service it provides to the citizens.

From the chi-squared statistical test of Table 4, one can conclude that most satisfied municipal employees work for large municipalities whereas the dissatisfied mostly work for minor ones. At the same time, a relatively big proportion of the satisfied employees working for large municipalities (for example, $47 \%$ of the employees in the municipality of Agrinion) declare satisfaction with their working conditions as well as stating that their superiors are particularly skilled and competent. Therefore, the level of satisfaction of the municipal employees with the large municipality they work for is linked to a certain extent with their working conditions and the skills of the head of their department.

While municipal employees assert that their working conditions have become more difficult due to the repercussions of the economic crisis (it was characteristically mentioned that they sometimes even lack the necessary stationery), this is not reflected on a low level of satisfaction regarding the respective partial satisfaction aspect. This is probably because the relatively high level of satisfaction with working conditions is mainly due to the satisfaction of those who serve in major municipalities. As a matter of fact, minor municipalities in terms of their population, number of employees and budget end up in a more adverse situation regarding the working conditions and workloads of their employees, given the 
loss of employees and the problem of understaffing due to the economic crisis, the massive budget cuts by the central government (as they are funded mainly by state subsidies) and often the inability of citizens to pay their municipal taxes and other fees. This is also confirmed by surveys carried out throughout the economic crisis in other public services (Pelechas \& Antoniadis, 2012).

Large municipalities are probably faced with those consequences of the crisis to a lesser extent, as their staff was and remains more numerous than that of small municipalities (even after the retirement of employees) and their administration and department heads are more competent and can deal with possible economic or other problems more effectively (as confirmed by the analysis).

The survey is an attempt to illustrate the level of job satisfaction of a specific category of public servants - that is, municipal employees in Greece in the context of the economic crisis. The examination of certain aspects of partial job satisfaction aims at improving public management, mainly on the basis of intrinsic rewards, in times of economic instability. The surveys conducted in the country regarding job satisfaction had been relatively limited in number, and those carried out after 2010, taking into account the economic crisis, were very few. Although geographically restricted in a single region of the country, the present survey is a contribution to the above. Further research on this subject is necessary, given that it is needed to thoroughly examine job satisfaction in public institutions of various categories, in comparison with each other, as well as in other regions (mainly in large urban agglomerations) where working conditions may be different. Lastly, in a framework of reorganization of the Greek public sector, not aiming at restricting expenditures but at improving effectiveness and quality, it is necessary to conduct further research on job satisfaction and its effect on performances.

\section{Conclusion}

In a period of deep crisis in the Greek economy, which is clearly reflected in high unemployment, underemployment and restricted salaries, municipal employees indirectly recognize (through their moderate job satisfaction) that they themselves continue to enjoy job security, even with massive income losses, in contrast with the unemployed or with the employed in the private sector, who seem to have lost more.

In this framework, municipal employees seem to have derived satisfaction or associated their job satisfaction with their immediate environment - that is, with the department where they serve, and with the administration of their immediate superiors. It could be considered that an organized department ends up being a refuge for employees, as it continues to function amid an economy in disarray and a society in confusion.

The survey demonstrates that, if public administration and local authorities pay due attention to selecting the heads and organizing the departments of public services, this will probably have a direct effect on improving job satisfaction among employees, with all the benefits that this entails, such as increased productivity and employee performance as well as enhanced services for the general public. 


\section{REFERENCES}

1. Alexias, G., Anagnostopoulos, F. \& Pilatis, I. (2010). Professional burnout and job satisfaction of the medical staff of the Athens public hospital. Epitheorisi Koinonikon Erevnon, no 131, pp. 109-136.

2. Bakotić, D. (2016). Relationship between job satisfaction and organizational performance. Economic Research, vol. 29, no 1, pp. 118-130. Available at: https://doi.org/10.1080/133167 7X.2016.1163946 (accessed: 14 January, 2019).

3. Batiou, V. \& Valkanos, E. (2008). Job Satisfaction of Public Administrative Personnel in Greece, International Journal of Academic Research in Business and Social Sciences, vol. 3, no 11, pp. $239-251$.

4. Boyne, G. (2003). Sources of Public Service Improvement: A Critical Review and Research Agenda, Journal of Public Administration Research and Theory, vol. 13, no 3, pp. 367-94.

5. Bourantas, D. \& Papalexandris, N. (1999). Personality traits discriminating between employees in public - and in private - sector organizations. The International Journal of Human Resource Management, vol. 10, no 5, pp. 858 -869.

6. Chatzitheodoridis, F., Kontogeorgos, A. \& Loizou, E. (2014). The Lean Years: Private Investment in the Greek Rural Areas. Procedia Economics and Finance, no 14, pp. 137-146. Available at: http://doi.org/10.1016/S2212-5671(14) 00695-9 (accessed: 14 January, 2019).

7. Cranny, C.J., Smith, P.C. \& Stone, E.F. (1992). Job Satisfaction: How People feel about their jobs and how it affects their performance. New York: Lexington Press.

8. Danzer, N. (2013). Job Satisfaction and Self-Selection into the Public or Private Sector: Evidence from a Natural Experiment, IZA Discussion Paper No. 7644, September 2013.

9. Demoussis, M. \& Giannakopoulos, N. (2007). Exploring Job Satisfaction in Private and Public Employment: Empirical Evidence from Greece. Labour, vol. 21, no 2, pp. 333-359, Available at: http://dx.doi.org/10.1111/j.1467-9914.2007.00370.x (accessed: 14 January, 2019).

10. Euro found (2016). Greece: Reducing the number of public servants - latest developments [online]. Available at: https://www.eurofound.europa.eu/observatories/emcc-eurwork/articles/ working-conditions-labour-market-industrial-relations/greece-reducing-the-numberof-public-servants-latest-developments (accessed: 20 January, 2018).

11. ELIAMEP (2015). Is it truth that the Greek public sector is huge? Crisis Observatory April 2015. No.4, Athens, Greece: Eliamep.

12. ELSTAT (2015). Labor Force Survey. Athens: Hellenic Statistical Authority.

13. ELSTAT (2017). Labor Force Survey: 1981-2015. Athens: Hellenic Statistical Authority.

14. Fassoulis, K. \& Alexopoulos, N. (2015). The workplace as a factor of job satisfaction and productivity: A case study of administrative personnel at the University of Athens. Journal of Facilities Management, vol. 13, no 4 pp. 332-349. Available at: https://doi.org/10.1108/ JFM-06-2014-0018 (accessed: 14 January, 2019).

15. Field, A. (2005). Discovering Statistics using SPSS. London U.K.: SAGE publicarían.

16. Georgelli, Y. \& Tabvuma, V. (2010). Does public service motivation adapt? Kyklos, vol. 63, no 2, pp. 176-191. 
17. Gould-Williams, J. (2003). The importance of HR practices and workplace trust in achieving superior performance: A study of public-sector organizations. The International Journal of Human Resource Management, no 14, pp. 28-54. Available at: https://doi. org/10.1080/09585190210158501 (accessed: 14 January, 2019).

18. Huczynski, A. \& Buchanan, A.D. (2013). Organizational Behaviour. $8^{\text {th }}$ Edition. Harlow, U.K.: Pearson Education ltd.

19. Ioannou, P., Katsikavali, V., Galanis, P., Velonakis, E., Papadatou, D. \& Sourtzi, P. (2015). Impact of Job Satisfaction on Greek Nurses' Health-Related Quality of Life. Safety and Health at Work, vol. 6, no 4, pp. 324-328.

20. Karkatsoulis, P., Michalopoulos, N. \& Moustakatou, V. (2005). The national identity as a motivational factor for better performance in the public sector: The case of the volunteers of the Athens 2004 Olympic Games. International Journal of Productivity and Performance Management, vol. 54, no 7, pp. 579-594. Available at: https://doi.org/10.1108/17410400510622241 (accessed: 14 January, 2019).

21. Jex, S.M. \& Britt, T.W. (2008). Organizational Psychology: A Scientist-Practitioner Approach. New York: John Wiley \& Sons.

22. Ladi, S. (2011). The Greek economic crisis: A trigger for public administration reforms? In: P. Liargovas (ed.). Greece: Economics, Political and Social Issues. New York: Nova Science Publishers, Inc.

23. Ladi, S. (2014). Austerity Politics and Administrative Reform: The Eurozone Crisis and its Impact upon Greek Public Administration, Comparative European Politics, vol. 12, no 2, pp. 184-208.

24. Luechinger, S., Meier, S. \& Stutzer, A. (2010). Why Does Unemployment Hurt the Employed? Evidence from the Life Satisfaction Gap between the Public and the Private Sector. Journal of Human Resources, vol. 45, no 4, pp. 998-1045.

25. Manolopoulos, D. (2006). An evaluation of employee motivation in the extended public sector in Greece. Employee Relations, vol. 30, no 1, pp. 63-85.

26. Markovits, Y., Davis, A.J. \& Dick, R. (2007). Organizational Commitment Profiles and Job Satisfaction among Greek Private and Public Sector Employees. International Journal of Cross Cultural Management, vol. 7, no 1, pp. 77-99.

27. Maroudas, T. (2009). The human factor and the quality to the Greek public sector. PhD Thesis, University of Macedonia, Thessaloniki (in Greek with English abstract).

28. Michalopoulos, N. (2003). From the Public Bureaucratic to the Public Management. Athens, Greece: Papazisis Publications.

29. Ministry of Interior and Administrative Reconstruction - MIAR (2016). The truth for the Greek Public Sector. Athens, Greece: Hellenic Republic Human Resources Registry.

30. Ministry of Interior and Administrative Reconstruction - MIAR (2017) Analytical data for Greek government personnel in the year 2016. Athens, Greece: Hellenic Republic Human Resources Registry.

31. Ostroff, C. (1992). The relationship between satisfaction, attitudes, and performance: An organizational level analysis, Journal of Applied Psychology, no 77, pp. 963-974. Available at: https://doi.org/10.1037/0021-9010.77.6.963 (accessed: 14 January, 2019).

32. Papanis, E. \& Yavrimi, P. (2007). Development of teachers' professional adaptation measurement scale: job satisfaction, professional stress and burnout [online]. Available at: http:// epapanis.blogspot.gr/2007/09/blog-post_20.html (accessed: 20 December, 2017). 
33. Perry, J.L. \& Wise, L.R. (1990). The motivational bases of public service. Public Administration Review, vol. 50, no 3, pp. 367-373.

34. Pelechas, E. \& Antoniadis, A. (2012). Comparative study of the satisfaction of medical and nursing staff in two hospitals in Greece”. Archives of Hellenic Medicine, vol. 30, no 3, pp. 325-334 (in Greek).

35. Pantouvakis, A. \& Mpogiatzidis, P. (2007). The impact of internal service quality and learning organization on clinical leaders' job satisfaction in hospital care services. Leadership in Health Services, vol. 26, no 1, pp. 34-49.

36. Prysmakova, P., Tantardini, M. \& Potkański, T. (2017). The Role of Financial Performance in Motivating Polish Municipal Employees. Review of Public Personnel Administration, First Published January 3, 2017. Available at: https://doi.org/10.1177/0734371X16685600 (accessed: 14 January, 2019).

37. Ritz, A. (2009). Public service motivation and organizational performance in Swiss federal government. International Review of Administrative Sciences, vol. 75, no 1, pp. 53-78.

38. Robbins, S.P. \& Judge, T.A. (2013). Organizational Behavior. $15^{\text {th }}$ Edition. New Jersey: Pearson Education ltd.

39. Sotiropoulos, D. (2007). State and Reform in Contemporary South Europe. Athens, Greece: Potamos.

40. Spector, P.E. (1997). Job Satisfaction: Application, Assessment, Causes, and Consequences. Thousand Oaks, CA: Sage Publications, Inc.

41. Spyropoulos, P., Papathanasiou, G., Georgoudis, G., Chronopoulos, E., Koutis, H. \& Koumoutsou, F. (2005). Prevalence of Low Back Pain in Greek Public Office Workers, Pain Physician, vol. 10, no 5, pp. 651-9.

42. Wright, E.B. \& Davis, S.B. (2003). Job Satisfaction in the Public Sector: The Role of the Work Environment. The American Review of Public Administration, vol. 33, no 1, pp. 70-90. Available at: https://doi.org/10.1177/0275074002250254 (accessed: 14 January, 2019). 